\title{
LA NAVE DE LA IGLESIA DE BERNARDO DE TORO Y EL BAJEL DE LA MAGDALENA DE LUIS DE ALCÁZAR: RECEPCIÓN A LO DIVINO DE MOTIVOS CLÁSICOS EN EL CANCIONERO SEVILLANO DE FUENMAYOR (SIGLOS XVI-XVII)
}

\author{
Elisabetta SARMATI \\ Sapienza, Università di Roma
}

\section{Introducción: el Cancionero de Fuenmayor}

En 1961 Dámaso Alonso, en un estudio pionero sobre el Cancionero sevillano de Fuenmayor, amén de proporcionar una serie de datos sobre la historia, el contenido y los autores de un códice hasta entonces inédito, lo calificaba como un ejemplo de conceptismo poético devoto de corte popular de finales del siglo XvI: «Es evidente», escribía, «el deseo del poeta de excitar, de sacudir la atención de un público probablemente hastiado ya de la reiteración de los mismos tópicos sobre unos cuantos temas». Según el estudioso, las justas poéticas en honor de santos, a lo largo del siglo XVI, «habían traído consigo la fatiga del público» ${ }^{1}$.

El Cancionero sevillano de Fuenmayor formó parte de la Biblioteca de Francisco Rodríguez Marín hasta ser adquirido en 1943 por la Biblioteca Central del CSIC, donde hoy se conserva. Toma nombre de una apostilla escrita por el mismo Rodríguez Marín en la página de guarda del códice R.M. 3879, donde consta a la letra que: «Este manuscrito lo vio Gallardo en 1844 en poder del Capitán Fuenmayor y figura en su Ensayo de una Biblioteca española con el n. ${ }^{0} 1048 »^{2}$. El mencionado estudio de

\footnotetext{
${ }^{1}$ Dámaso Alonso, «Para la historia temprana del conceptismo: un manuscrito sevillano de justas en honor de santos (de 1584 a 1600)», Archivo hispalense, 109 (1961), pp. 1-33, después en Dámaso Alonso, Obras completas, III. Estudios y ensayos sobre literatura. Segunda parte. Finales del siglo XVI y siglo XVII, Madrid, Gredos, 1974, pp. 75-114, p. 107. Anteriormente Alonso ya se había ocupado tangencialmente de este manuscrito en su libro sobre el poeta Francisco Medrano. Véase Dámaso Alonso y Stephen Reckert, Vida y obra de Medrano, Madrid, CSIC, 1958, vol. 2, pp. 349-359.

${ }^{2}$ Bartolomé José Gallardo, Ensayo de una biblioteca española de libros raros y curiosos, Madrid,
} 
Alonso $^{3}$, un trabajo de Antonio Rodríguez Moñino ${ }^{4}$ que incluye la presentación de otros dos manuscritos congéneres (el Cancionero de Jesuitas y el Rosal de divinos versos ${ }^{5}$ ) y el «Estudio preliminar» de José J. Labrador Herraiz, Ralph A. DiFranco y José Manuel Rico García a la edición moderna del Fuenmayor ${ }^{6}$ son hasta hoy las únicas referencias bibliográficas de las que disponemos sobre este Cancionero.

El Fuenmayor es un cancionero sevillano de poesía religiosa. La mayoría de sus autores, que Alonso prefiere calificar de «rimadores de excelente oficio» ${ }^{7}$ más que de poetas, pertenecen a la orden de la Compañía de Jesús ${ }^{8}$. Según Rodríguez Moñino, su recopilador «fue algún padre de la Compañía quien se ocupó de reunir materiales dispersos existentes en el convento» ${ }^{9}$. Este eligió a su gusto poemas que se componían para las fiestas religiosas locales, en ocasión de certámenes poéticos y obró, posiblemente, en la casa profesa de los jesuitas. Sin embargo, a pesar del carácter ocasional y arbitrario de su recopilación, el Fuenmayor tiene una dimensión menos "fragmentaria" que otros cancioneros, debido a su intención religiosa, a la procedencia sevillana de sus autores y a las fechas bastante cercanas de sus piezas, factores que le otorgan una impronta poética bastante coherente. De los 249 poemas que lo componen, el primero está datado en 1584, mientras el último es de $1600^{10}$. El género poético más representado es el de la "justa" que, como advierte Alonso, no designaba el propio certamen literario sino una composición de doce quintillas que su copista empareja de dos en dos, dando origen a seis quintilla dobles, denominadas también coplas castellanas ${ }^{11}$. Canciones,

Imprenta y Estereotipia de M. Rivadeneyra, 1863, 4 vols., I, n. 1048, disponible en $<$ http://descargas. cervantesvirtual.com/servlet/SirveObras/06921735377928773432268/035551.pdf>. El Capitán Pedro Fuenmayor de la Fuente fue militar y poeta, nacido en Sevilla en 1783. Escribió odas e incursionó en el género dramático con las tragedias: Galería (1820) y María Stuard, reina de Escocia y Aldaguisa, hija de Didier último rey lombardo (1821).

${ }^{3}$ Véase Alonso, «Para la historia temprana», art. cit.

${ }^{4}$ Véase Antonio Rodríguez-Moñino, Tres cancioneros manuscritos. (Poesía religiosa de los siglos de oro), Ábaco. Estudios sobre la literatura española, 2 (1969), pp. 127-272 y 3 (1970), pp. 87-227.

${ }^{5}$ Véase Alonso, «Para la historia temprana», art. cit.; Rodríguez-Moñino, «Tres cancioneros manuscritos», art. cit.

${ }^{6}$ Véase Cancionero sevillano de Fuenmayor, ed. y estudio preliminar de José J. Labrador Herraiz, Ralph A. DiFranco, José Manuel Rico García, Sevilla, Universidad, 2004.

${ }^{7}$ Alonso, «Para la historia temprana», art. cit., p. 113.

${ }^{8}$ Además de los jesuitas, que constituyen el $80 \%$ de sus autores, en el Fuenmayor se encuentran autores seglares especialistas en justas a santos y autores religiosos que «dan clara muestra de haber nacido en el ambiente de otras órdenes» (ibídem, p. 94), como dominicos, franciscanos y augustinos.

${ }^{9}$ Rodríguez-Moñino, «Tres cancioneros manuscritos», art. cit., p. 137.

${ }^{10}$ Según el cálculo de Labrador Herraiz, DiFranco y Rico García, que corrigen a Rodríguez Moñino, véase el estudio preliminar en Cancionero sevillano de Fuenmayor, ed. cit., pp. 19-53, p. 23.

${ }^{11}$ Alonso, «Para la historia temprana», art. cit., p. 77. 
chanzonetas, epigramas en latín, liras, octavas, redondillas, romances, sonetos, villancicos, etc. son otros de los metros presentes. La mayoría de los autores pertenecen a la orden religiosa de la Compañía de Jesús. El título de Hermano se alterna al de Padre, según una lógica no totalmente diáfana. «Es posible (pero no seguro) que varios de los mencionados como "hermanos" fueran jesuitas que no hubieran cantado aún misa» ${ }^{12}$, o sea que aún no se habían consagrado como sacerdotes.

Alonso propone un número consistente de ejemplos de este conceptismo devoto destinado a un público piadoso. El crítico pone de manifiesto «juegos de palabras e ingeniosidades que a menudo rozan lo irreverente. El poeta devoto tiene que maravillar a su público, aunque sea produciéndole una sacudida, casi un choque brutal» ${ }^{13}$. Como muestra de este incipiente conceptismo y sin alejarnos del motivo de la descriptio tempestatis objeto de este trabajo, léanse las siguientes redondillas anónimas a Santa Marta (texto n. 55), donde al tópico del viaje marítimo como translatio de la escritura poética, bien documentado históricamente por Curtius ${ }^{14} \mathrm{y}$ desarrollado en las dos primeras estrofas, se añade el calambur marta = mar harta que reutiliza la metáfora marina a partir del mismo nombre de la santa, según el principio del nomen omen, para concluir con Santa Marta piloto de un barco seguro en medio de los abismos.

Mi pluma y tosco pinzel
tomé descuidado, y temo
que buelta la pluma en amo
á de ser agua el papel.

Y agua tanta para llegar al puerto de Sancta Martha que el echo dize que es arta porque su prinçipio es mar.

Pero si todo el abismo, en su nombre Martha ençierra, jamás el mar le hará guerra porque se la hará a sí mismo.

Y tan en leche estará que vn barco sin jarçias roto,

${ }^{12}$ Ibídem, p. 85.

${ }^{13}$ Ibídem, p. 107.

${ }^{14}$ Ernst Robert Curtius, Literatura europea y Edad Media Latina, México, Fondo de Cultura Económica, 1955, 2 vols., I, pp. 189-193. 
aunque muger sea el piloto, si sois vos, se saluará.

Como al fin sin gobernalle y con gobernalle en vno, vos, Martha, fuiste Neptuno haziendo en las aguas calle.

Un aspecto que puede considerarse otra faceta de este incipiente conceptismo devoto es el proceso de reescritura a lo divino de temas y motivos profanos que en el Fuenmayor presenta textos de cierto interés. De hecho, la poesía de este Cancionero se inscribe perfectamente en aquel proceso de divinización que afecta a todo género de obra profana de los siglos XV-XVII, convirtiendo en materia didáctico-religiosa temas, motivos, metáforas e imágenes poéticas, según una técnica de reescritura que culmina en la poesía de los grandes místicos del Renacimiento español, San Juan de la Cruz y Santa Teresa de Ávila ${ }^{15}$. Si las notas de la edición moderna de Labrador, DiFranco y Rico García documentan la contrafactura religiosa de villancicos, estribillos y romances tradicionales, como es por ejemplo el caso concreto del texto $\mathrm{n}$. $22^{16}$, hasta hoy resulta inexplorado el caudal de imágenes que el Fuenmayor aporta a la reescritura sagrada de la tópica poética de los Siglos de Oro.

\section{La Nave de la Iglesia de Bernardo de Toro}

Uno de los iconos más presentes y mejor utilizados en el Cancionero de Fuenmayor es el motivo clásico de la navegación alegórica, en todas las posibles variantes que se han impuesto a lo largo de la historia literaria ${ }^{17}$.

${ }^{15}$ Para los orígenes de la poesía a lo divino en la Península, véase Dámaso Alonso, «El misterio técnico de la poesía de San Juan de la Cruz», en Poesía española. Ensayo de métodos y límites estilísticos [1950], Madrid, Gredos, 1971, pp. 219-305, que señala como la vuelta a lo divino empieza en España con el Eya velar de Gonzalo de Berceo (ibídem, p. 230). De la misma opinión es Bruce Wardropper, Historia de la poesía lírica a lo divino en la Cristiandad occidental, Madrid, Revista de Occidente, 1958, p. 95, mientras que para Eugenio Asensio el género comenzaría con una danza de mayo presente en la Cantigas de Alfonso el Sabio: véase Eugenio Asensio, reseña a: Pierre Le Gentil, La poésie lyrique espagnole et portugaise á la fin du Moyen Ầge, Revista de Filología Española, 42 (1959), p. 301. En general sobre el tema, véanse Francisco Javier Sánchez Martínez, Historia crítica de la poesía lírica culta «a lo divino» en la España del Siglo de Oro, Madrid, Ed. Autor, 1995 y María José Martínez López, «Garcilaso a lo divino: de la letra a la idea», Criticón, 74 (1998), pp. 31-43, p. 31.

${ }^{16}$ Se trata del estribillo «Vente, amor, vente, / que en verte amanesçe» del romance n. 22, De el amor divino preso, reescritura a lo divino del conocido villancico tradicional: «Vete, amor, y vete/ cata que amanece» (cfr. «Notas», en Cancionero sevillano de Fuenmayor, ed. cit., p. 450; Margit Frenk Alatorre, Nuevo corpus de la antigua lírica popular hispánica (siglos XV a XVII), México, UNAM, 2003, p. 328).

${ }^{17}$ Para la tradición literaria clásica, véanse Ettore Paratore, «Da Plauto al Mare Amoroso», en Studi 
Naufragios, tormentas y naves alegóricas son componentes figurativos de discreto impacto también en el discurso poético de tema religioso y cubren un campo semántico muy amplio. En algunos poemas, las metáforas marineras se presentan sólo con componentes aislados. Se habla del dulçe o seguro puerto de la fe ${ }^{18}$; del mar alborotado del pecado ${ }^{19}$; de la Cruz como farol del afligido navegante ${ }^{20}$, de Cristo divino piloto de la nao de su humanidad y de la Vírgen mar de bondad ${ }^{21}$, hasta llegar al viaje marítimo como translatio de la escritura poética, como ya se ha observado a propósito de las redondillas a Santa Marta. En otros poemas, en cambio, la alegoría de la tormenta marina presenta una narración más elaborada. Por ejemplo, en la canción El glorioso San Miguel (texto n. 40) de Bartolomé Leonardo de Argensola -uno de los autores seglares más conocidos del Fuenmayor, junto con Fray Luis de León y Juan de Arguijo- el motivo de la tormenta marina viene a representar la furia del arcángel en la batalla contra Lucifer, según el libro del Apocalipsis 12,7. San Miguel es: «corriente que a la mar da su tributo / y el mar cuando no sólo al suelo enjuto / mas al cielo y estrellas guerra mueve / tiranizado por contrarios vientos $\rangle^{22}$.

En la octava que cierra el texto n. 52 de Ambrosio de Torres ${ }^{23}$ (cuya rúbrica reza: A una pintura de una aguja de marear de puntas amarillas y de color de jacinto, con una flor de color carmesí que miraba hacia donde estaua una estrella. Con esta letra «magnes autem erat Christus»), la alegoría general del piloto en el mar tempestuoso en busca de un simbólico puerto, cuyo norte es Cristo, se despliega en una narración salvífica, construida alrededor de la imagen de una aguja náutica. Jacinto es el nombre del santo al que la composición está dedicada:

Qualquiera que con rumbo y norte çierto quisiere sin temor del mar ayrado

in onore di A. Schiaffini, número monográfico de Rivista di cultura classica e medievale, 2 (1965), pp. 824-860 y Andrea Pulega, Da Argo alla nave d'amore: contributo alla storia di una metafora, Firenze, Olschki, 1989, p. 9. Para una difusión del tema en área hispánica, véase Elisabetta Sarmati, Naufragi e tempeste d'amore. Storia di una metafora nella Spagna dei Secoli d'Oro, Roma, Carocci, 2009.

${ }^{18}$ V. 56, texto n. 30, El primo hermano de Christo; v. 17, texto n. 36, Si de Dios el pecho abierto; v. 2, texto n. 71, Alma que el mundo por tu Dios dexaste, etc.

${ }^{19}$ Vv. 31-35, texto n. 56, Con magestad y aparato.

${ }^{20} \mathrm{~V}$. 26, texto n. 82, Resplandeçiente, dulçe, amena planta.

${ }^{21} \mathrm{Vv}$. 46-50, texto n. 156, El gran nebli que en el cielo.

${ }^{22}$ Las cursivas en los textos citados son mías.

${ }^{23}$ Muy escasos los datos biográficos sobre este autor. Dámaso Alonso señala que un jesuita con el nombre de Ambrosio de Torres «se encuentra entre los testigos en las informaciones hechas en Sevilla en el proceso de las virtudes de Fernando de Contreras», véase Dámaso Alonso, «Para la historia temprana», art. cit., p. 83 . 
surgir con brevedad en dulçe puerto, flotar puede un navío que aprestado con municiones y piloto experto muestra en la aguja un lirio colorado al qual dexar al norte nadie ha visto por ser tocado en piedra imán que es Christo (vv. 33-40).

De procedencia más claramente petrarquista es el frágil nauichuelo (la frale o debile barca con la que el escritor aretino aludía al amante-poeta) ${ }^{24}$, que representa, entre otras imágenes, al yo del pecador en los vv. 338-345 del texto n. 136, titulado Breve relación de la vida y muerte del hermano Gaspar Sánchez:

Pedía de ordinario al Rey del çielo con continua oraçión y afecto tierno, viendo tantos caminos en el suelo -y que todos prometen puerto eterno-, librasse aquel su frágil nauichuelo de los tristes baxíos del infierno, porque estaba engolfado y no sabía a qué parte la proa boluería.

Al lado de la más general analogía velero-poeta o velero-pecador, el Fuenmayor presenta otras interesantes configuraciones de naves alegóricas, como la nave de la Iglesia de Bernardo de Toro, que ocupa enteramente el soneto Oy echa al agua aquesta naue nueva (texto n. 42) ${ }^{25}$. La tradición iconográfica de la nave de la Iglesia tiene su raíz en los prototipos bíblicos del arca de Noé y de la barca de San Pedro, cuya potencialidad alegórica fue abundantemente aprovechada por la patrística, en los nombres de San Ambrosio, San Hipólito, San Jerónimo, etc ${ }^{26}$. Jean Daniélou en Les Symboles chrétiens primitifs ${ }^{27}$ y

\footnotetext{
${ }^{24}$ Francesco Petrarca, Canzoniere. Rerum vulgarium fragmenta, ed. de Rosanna Bettarini, Torino, Einaudi, 2005, 2 vols., cxxxII y cxxxv.

${ }^{25}$ De la nave-estado de Alceo (vII siglo a. C.), que en área ibérica encuentra aclimatación a partir de las coplas di Fray Íñigo de Mendoza dedicada a los Reyes Católicos para que salven la «barca castellana» del naufragio, las naves alegóricas presentan una larga y variada tradición literaria. Naves-Estado son también las de Gonzalo Martínez de Medina, Por nuestros pecados Saturno se enflama (en Cancionero de Juan Alfonso de Baena, ed. de Brian Dutton y Joaquín González Cuenca, Visor, Madrid 1993, n. 333, p. 588) y de Alfonso Álvarez de Villasandino, Amigo señor, yaziendo en mi cama (ibídem, n. 334, p. 589), ambas consideradas anteriores al 1411.

${ }^{26}$ Hugo Rahner, Symbole der Kirche. Die Ekklesiologie der Väter, Salzburg, Müller, 1964.

${ }^{27}$ Jean Daniélou, Les Symboles chrétiens primitifs, Paris, Seuil, 1961, trad. esp. Los símbolos cristianos primitivos [1961], Bilbao, Ega, 1993, pp. 53-62. Sobre el simbolismo eclesial de la nave, véase también Fabrizio Bisconti, Temi di iconografia paleocristiana, Roma, Pontificio Istituto di Archeologia Cristiana-PIAC, 2000.
} 
Hugo Rahner en Symbole der Kirche ${ }^{28}$, alegando testimonios de la literatura apologética y homilética cristiana, explican la relación entre la nave y su sentido salvífico con las mismas características plásticas del icono. Si, por ejemplo, para San Ambrosio el mástil de la nave remite a la misma figura de la Cruz salvadora ${ }^{29}$, en la epístola de San Clemente al obispo Santiago de Jerusalén, que precede sus Veinte homilías: «todo el cuerpo de la Iglesia se parece a una gran nave que transporta hombres de muy diversa procedencia, en medio de una gran tormenta» ${ }^{30}$.

La alegoría de la nave eclesial puede presentarse de forma muy articulada ya desde sus primeras apariciones, con Dios dueño de la nave, Cristo como piloto, los sacerdotes que ejercen de marineros, los catequistas de grumetes etc., como en la epístola del Santo, donde la alegoría sigue comparando la tormenta marina con las tentaciones del mundo ${ }^{31}$. Es El anticristo de San Hipólito el primer texto que presenta un sistema extenso de metáforas superpuestas relativo a la nave de la Iglesia. Aquí la nave (de la Iglesia) surca el mar (mundo), con Cristo como timonero; el palo es la cruz y los travesaños de la escalera que sube al mástil los pasos de Jesús en su camino hasta el Calvario ${ }^{32}$ : «la tradición católica hace de la Iglesia, por tanto, el único seno en que el cristiano puede esperar salvación y llegar con bien al puerto celestial, fuera de ella la condena es segura ${ }^{33}$.

Para la España medieval, Alberto Navarro González alega un buen inventario de naves eclesiales, cuyos ejemplos más destacados se encuentran en la Vita Christi de Francesc Eiximenis, con una mención a los apóstoles que salvan con sus redes a los pecadores cargándolos en la nave de la santa fe católica; en el Rimado de Palacio de Pero López de Ayala con su «nao de Sant Pedro» que «passa grant tormenta» ${ }^{34} \mathrm{y}$, a principios del siglo XVI, en Los doce triunfos de los doce Apóstoles de fray Juan de Padilla, con una navicula Petri que «nunca teme de verse perdid[a], / teniendo por remo los diez mandamientos $»^{35}$.

\footnotetext{
${ }^{28}$ Rahner, Symbole der Kirche, ob. cit.

${ }^{29}$ Cfr. Juan Luis Calbarro, «"Nauis Ecclesiae". Origen e interpretación de una joya iconográfica de Betancuria», Tebeto. Anuario del Archivo Histórico Insular de Fuerteventura, 15 (2002), pp. 291-318, p. 297 y ss.

${ }^{30}$ Daniélou, Los símbolos cristianos primitivos, ob. cit., p. 53.

${ }^{31}$ Ibidem.

${ }^{32}$ Cfr. Alberto Navarro González, El mar en la literatura castellana, La Laguna, Universidad de la Laguna, 1962, pp. 444-446 y Juan Ruiz Alceo, La navegación de Ulises: auto sacramental, Kassel-Pamplona, Edition Reichenberger-Universidad de Navarra, 1993, pp. 14-15.

${ }^{33}$ Calbarro, "“Nauis Ecclesiae"», art. cit., p. 298.

${ }^{34}$ Navarro González, El mar en la literatura castellana, ob. cit. y Pero López de Ayala, Libro rimado del Palaçio, ed. de Jacques Joset, Madrid, Alhambra, 1978, p. 294.

${ }^{35}$ La cita es indirecta: véase Calbarro, «"Nauis Ecclesiae”», art. cit., p. 300.
} 
La nave de la iglesia de Bernardo de Toro enriquece el número de antecedentes literarios sobre el simbolismo eclesial y salvífico de la nave que surca indemne las olas tempestuosas de la vida terrenal, motivo que llegará a ser recurrente en la literatura aurisecular, sobre todo en los autos sacramentales de Lope de Vega, como recuerdan Mariela Insúa Cereceda y Carlos Mata Induráin, que señalan también otro antecedente de nave eclesiástica en un desconocido romance mariano de Juan de Amiax y de Calderón de la Barca (como apunta Ignacio Arellano en su Diccionario de los autos sacramentales calderonianos $^{36}$ ).

Según Dámaso Alonso los tres autores presentes en el Fuenmayor bajo los nombres de H. B. De Toro, H. Toro y P. Toro se deben reconducir todos a Padre Bernardo de Toro, nacido en Sevilla en 1570, discípulo de P. Hernando de Mata y muy activo en el movimiento sevillano de la proclamación del dogma de la Inmaculada Concepción. Murió en Roma en 1643. La letra H. es abreviatura de Hermano ${ }^{37}$. Este soneto pertenece a un ciclo de 14 composiciones dedicadas a San Jacinto (textos nn. 41-54), con motivo de la fiesta de canonización del Santo en el convento de San Pablo en Sevilla en 1595. La alegoría de la nave de la Iglesia estructura cuartetos y tercetos.

Oy echa al agua aquesta naue nueva el gran piloto de la Iglesia sancta, con tal virtud que sola el mar quebranta $\mathrm{y}$ al enemigo que sus fuerças prueba.

El negro manto sobre el agua lleva, y en el qual firme maestra se leuanta Jacinto, naue a quien la mar no espanta por más tormentas que en sus senos mueua.

Firme esperança tiende al viento velas, fee viua el norte de su intento guía, puerto seguro ve su ardiente zelo.

\footnotetext{
${ }^{36}$ Cfr. Mariela Insúa Cereceda y Carlos Mata Induráin, «La alegoría de la nave de la iglesia en un romance mariano de Juan de Amiax», Príncipe de Viana, 232 (2004), pp. 639-667; Ignacio Arellano, «Nave de la Iglesia», en íd., Diccionario de los autos sacramentales de Calderón, Kassel-Pamplona, Edition Reichenberger-Universidad de Navarra, 2000, p. 158 e íd., Estructuras dramáticas y alegóricas en los autos de Calderón, Kassel-Pamplona, Edition Reichenberger-Universidad de Navarra, 2001, pp. $84-85$ y pp. $160-161$.

${ }^{37} \mathrm{Cfr}$. Alonso, «Para la historia temprana», art. cit., pp. 92-93.
} 
Con tales alas por el agua buelas, tal norte te da alegre y claro día, Jacinto, y firme amor, por paga, el çielo.

El simbolismo de la nueva embarcación de la Iglesia sancta, del gran piloto-Jacinto (vv. 1-2), y de las tres virtudes teologales: la fe: guía y norte de la navegación (v. 10), la esperanza: motor y velas de la nave (v. 9), y la caridad: su puerto (v. 11), matiza un sintético discurso figurado en torno al tema de la vida como viaje nocturno (el negro manto de la noche) por mar en medio de una tormenta. Sólo la nave de la Iglesia consigue surcar incólume las olas con destino cierto.

En el Cancionero de Fuenmayor, al lado de tormentas morales y naves eclesiales, el motivo del mar y de la navegación llega a simbolizar, como en la lírica profana, una experiencia de carácter amoroso, aquí de caritas, amor cristiano. Es el caso del villancico n. 27, Quán discreto y desenbuelto, que pertenece a un ciclo de composiciones dedicado a San Juan el Evangelista, titular de la cofradía de Monte Sión de Sevilla fundada en 1560. Se trata de un villancico que glosa el refrán de apertura «A río revuelto, ganancia de pescadores», utilizando el motivo de la tormenta amorosa para estigmatizar el sentimiento que une a Cristo con el apóstol que la tradición cristiana identifica con el «discípulo a quien Jesús mucho amaba» (Juan 13, 21-26; 20, 1-10; 21, 20-22). También aquí el tópico ocupa enteramente el poema:

Quán discreto y desenbuelto

os hazen, Juan, los amores.

Muy bien dizen que a río buelto, ganançia de pescadores.

En el agua sosegada del seno del mar, de amor no se hallaua pescador que pudiesse pescar nada. Mas ya el mar está rebuelto, ya ay olas y temblores:

llegas, Juan, que a río buelto, ganançia de pescadores.

Ya está Dios en nuestro suelo, ya llora, tiembla y padeçe, ya la ola tanto creçe que nos junta con el çielo. 
El tiempo está ya rebuelto, Aora es tiempo de amadores: muy bien dizen a río buelto, ganançia de pescadores.

Mirad que en el sancto pecho sopla un viento de amor fuerte, el qual lleva a Dios a muerte, de nuestro bien satisfecho. Echad el anzuelo embuelto en çeuo de sus amores, porque dizen que a río buelto, ganançia de pescadores.

\section{El Bajel de la Magdalena de Luis de Alcázar}

Vinculado estructuralmente a la tradición hispánica de las naves de amor, en cambio, es el romance de Luis de Alcázar, Vuestro baxel Magdalena, texto n. 65 del Fuenmayor ${ }^{38}$. El bajel o carabela de la Magdalena de Alcázar presenta un esquema alegórico parecido al propuesto en la Nave de Juan de Dueñas que, junto a la Nao del Comendador Escrivá, es ciertamente la más famosa del género profano ${ }^{39}$. En el género de las naves de amor, la serie de correspondencias entre las partes de la embarcación y los alcances metafóricos se amplía con respecto al patrón petrarquista, según un esquema de correspondencias minuciosamente señaladas, hasta constituir una verdadera gramática de los estados de ánimo de la psicología amorosa. Los avatares del piloto-enamorado, que arma su bajel para surcar las impracticables aguas

${ }^{38}$ Sobre Luis de Alcázar, véase Alonso, «Para la historia temprana», art. cit., p. 83: «El P. Luis de Alcázar nació en Sevilla, de ilustre linaje; era hijo del venticuatro Melchor de Alcázar, sobrino del poeta Baltasar y hermano del también venticuatro y poeta Juan Antonio. Enseñó en su patria y en Córdoba. Murió en Sevilla en 1613, a los 63 años».

${ }^{39} \mathrm{La}$ Nao de amor de Juan de Dueñas, compuesta en torno a 1437 y presente en más de doce Cancioneros, es ciertamente la más famosa del género profano. Estrechamente vinculada al texto de Dueñas es la Nao del Comendador Escrivá, poeta de la segunda mitad del siglo xv. Sobre el género de la Nao en el siglo xv, véanse Giovanni Caravaggi, «La Nao de amor de Juan de Dueñas», Annali dell'Istituto Universitario Orientale di Napoli. Sezione Romanza, 30: 1 (1988), pp. 123-127; íd., «La "Nao de Amor" del Comendador Juan Ram Escrivà», en Literatura hispánica. Reyes Católicos y Descubrimiento. Actas del Congreso internacional sobre literatura hispánica en la época de los Reyes Católicos y del Descubrimiento, Barcelona, Promociones y Publicaciones Universitarias, 1989, pp. 248-258; Marco Presotto, «Studio introduttivo», en Juan de Dueñas, La Nao de amor, Misa de Amores, ed. de Marco Presotto, Viareggio-Lucca, Mauro Baroni, 1997, pp. 11-93; Ines Ravasini, «Introduzione», en Comendador Escrivá, Poesie, ed. de Ines Ravasini, Viareggio-Lucca, Mauro Baroni, 2008, pp. 9-77. Véase también Sarmati, Naufragi e tempeste, ob. cit., pp. 55-89. 
del amor, terminan en una derrota total: el bajel va a la deriva. De Naves de amor abunda también la lírica petrarquista española de los siglos XVI-XVII, que a partir del soneto CLIIIXIX del Rerum Vulgarium Fragmenta de Petrarca, da inicio a una larga serie de imitaciones afortunadas como los sonetos En alta mar rompido stá el navío de Juan de Boscán; Tibio en amores no sea yo jamás de Diego Hurtado de Mendoza; Rompió la proa en dura roca abierta de Fernando de Herrera, etc., y, sobre todo, las barquillas o romancillos piscatorios de Lope ${ }^{40}$.

En el Fuenmayor a la Magdalena están dedicadas 12 piezas, que constituyen una justa relacionada con el culto hispalense de la Santa, nacido en torno a la Iglesia sede de Hermandad Sacramental de la Magdalena. Exactamente se trata de los textos n. 1, 5, 6-9 y 61-66, de metros variados (romances, liras, sonetos, epigramas), todos anónimos hasta el n. 61 incluido. El soneto n. 62 es de cierto Padre Rueda, el 63 del hermano Salas y el 66 de Miguel çid, el epigrama 64 y el soneto 65 son de Luis de Alcázar.

Figura bíblica, a veces identificada como la esposa de Cristo, la Magdalena es personaje muy controvertido. El Fuenmayor sigue en sus poemas la tradición cristiana que ha unido en este personaje a tres tipos de mujeres del Nuevo Testamento, María de Magdala arrodillada al lado de la Virgen bajo la Cruz durante la crucifixión de Jesús y que llora abrazada a sus pies (Mt. 27, 56 ss; Mr. 15, 40; Gv. 19, 25), la mujer que asiste a su Resurrección (Mt. 28, 1 ss., 56 ss; Mr. 15, 47; Lc. 24, 10; Gv. 20, 1), y la pecadora, mujer adúltera, que reconoce sus pecados, y que se presenta en la casa de Simón el fariseo para pedir perdón a Jesús, mojándole los pies con sus lágrimas, enjugándoselos con sus largos cabellos y perfumándolos con un ungüento aromático. Los textos del Fuenmayor, más inclinados hacia una devoción de carácter popular, como notaba ya Dámaso Alonso ${ }^{41}$, celebran a este último personaje, síntesis de amor sacro y profano: la mujer que peca porque ha amado mucho, según Lucas, 7, 36-50, y la presenta con los atributos iconográficos más recurrentes de Tiziano a Caravaggio: un vaso de perfume en las manos, el pelo muy largo y las copiosas lágrimas, que en el romance de Alcázar se configuran metafóricamente como elementos de una navegación de amor cristiano: lágrimas $=$ mar; mercancía $=$ ungüento; pasajeros $=$ culpas; cabellos $=$ amarras; roca, puerto, piloto $=$ Cristo.

${ }^{40}$ Véanse Joseph G. Fucilla, «Concerning the Poetry of Lope de Vega», Hispania, 15 (1932), pp. 223-242; Edward S. Morby, «A Footnote on Lope de Vega's 'barquillas'», Romance Philology, 6 (1953), pp. 289-293 y Alberto Navarro González, «Poesía marinera de Lope de Vega», en Homenaje al profesor Emilio Alarcos García, Valladolid, Universidad, 1965-1967, 2 vols., II, pp. 369-389.

${ }^{41}$ Ibídem, p. 106 y ss. 
La nave de la Magdalena ${ }^{42}$ se presenta segura, más segur[a] que en bonanza (v. 4), en medio de la borrasca (v. 8). La personificación barca = Magdalena se articula, como la alegoría suele presentarse tradicionalmente, en correspondencias detalladas, si bien fuera de los más consuetos tecnicismos: fusta ligera $=$ el alma (v. 10); xarçias $=1$ los desseos (v. 11), árbol = la esperanza (v.12); vientos $=$ los gemidos (v. 13); mesana $=$ la oración (v. 13); el timón = el temor (v. 15), etc.

Vuestro baxel, Magdalena, va por la diuina graçia entre las terribles olas más seguro que en bonança. Hierue el mar de vuestro pecho, llega a el çielo la resaca y para tomar el puerto es el medio la borrasca. Las lágrimas son el mar, la fusta ligera, el alma, las xarçias son los desseos y el árbol es la esperança. Los gemidos son los vientos y la oración la mesana el timón es el temor de Dios y de su desgraçia. Los cuidados son los remos y la vergüença es el ancla, la mercançía el vngüento de suauísima fragrançia. Las culpas los pasageros que al salir dexan ganançia, y el piloto es el amor que en esta derrota manda. Abre Christo todos senos del gran puerto de tu graçia, y acoge a la carauela que nauega en tu demanda.

${ }^{42} \mathrm{El}$ motivo de la nave de la Magdalena radica, posiblemente, en la leyenda provenzal que narra la llegada de la Santa, procedente de Palestina, por mar a Provenza. Sobre la fortuna de motivos magdalenianos en área ibérica véase Blanca Periñan, Sobre 'conversiones' barrocas, en Pictavia aurea. Actas del IX Congreso de la Asociación Internacional "Siglo de Oro" (Poitiers, 11-15 de junio de 2011), ed. de Alain Bègue y Emma Herrán Alonso, Toulouse, Presses Universitaires du Mirail (Anejos de Criticón, 19), 2013, pp. 57-77 y bibliografía allí citada. 


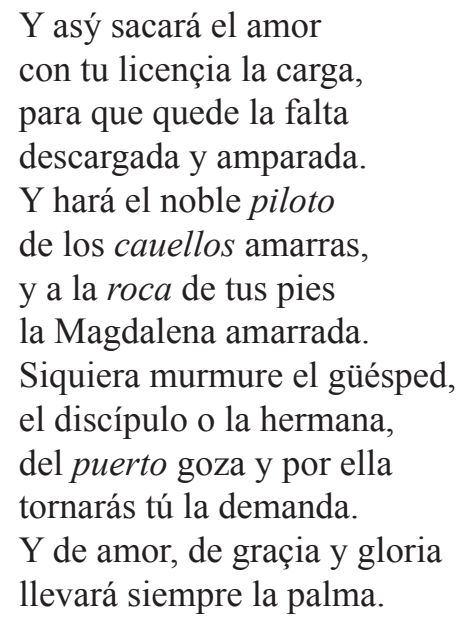

Precede y parafrasea al romance el texto $n .^{\circ}$ 64. Se trata de un epigrama en latín, con su traducción al castellano, que se transcribe a continuación, donde las metáforas marítimas resultan aún más diáfanas. Esta reduplicación testimonia el sustancial carácter de variatio en torno y sobre un tema de estas composiciones:

Tuta per undantis refluos tibi pectoris aestus, Magdala diuino munere pupis abit. Unda tibi lachrimae, mens navis vota rudentes spes malus gemitus flamma vela preçes, temo timor veni, cura pudor anchora merces unguentum omites crinina. Vector amor pande rati tu Christe sinus et hospitus hospes secum indignant murmura saeva fremat hin merces deponent amor pupinque ligabit caves sunt plantae ducta que vincla comae.

Segura a través del impetuoso flujo del oleaje de tu pecho, Magdalena, con su recompensa divina la barquilla se aleja. Tus lágrimas las olas; tu pensamiento la nave; tus deseos, las jarcias; el mástil, la esperanza; tu llanto, los vientos; las velas, los ruegos; el timón es tu miedo; los remos, tu cuita; tu vergüenza, el ancla; la mercancía, el perfume; los compañeros, tus pecados; el amor tu guía. Abre, Cristo, a la barquilla tu regazo y que entre los salvados, salvada, consigo misma indignándose, brame crueles murmullos. Entonces, el amor llevará a tierra la mercancía y amarrará la popa. Rocas son tus pies y las amarras tu cabellera. 
En el caso de las dos piezas de Luis de Alcázar, como de otra composición dedicada a la Santa, el soneto anónimo n. ${ }^{\circ}$ 5: Estaua Magdalena contemplando, el Fuenmayor se hace cargo también de una variante ocasional, pero muy temprana, en la más común alegoría del naufragio amoroso, variante presente tanto en la lírica de Boscán como en la de $\mathrm{Garcilaso}^{43}$, que es la posibilidad de eludir un naufragio anunciado, en este contexto gracias a la fe y a la caritas, como se sintetiza en el último terceto:

Estaua Magdalena contemplando

en su pecho a Jesús, por quien moría.

Ella misma se habla y respondía, que lo tenía delante imaginando.

De sus hermosos ojos destilando lo que orientales perlas paresçía, con voz, que al cielo mueue, assí dezía, su cristalino rostro levantando:

"No viva yo sin ti, dulçe amor mío, de mí sola por ti quede oluidada, pues no tengo otro ser ni otra esperança.

Tu fee sola es, Jesús, en quien me fío, y en ese blando pecho aposentada, qualquiera tempestad será bonança.

Dámaso Alonso, a conclusión de su estudio sobre el Fuenmayor, se preguntaba hasta qué punto este cancionero podía considerarse interesante literariamente, amén de serlo para una mejor comprensión de los rasgos peculiares de la devoción popular española de fines del siglo Xvi. Desde el punto de vista que él adoptaba, llegaba a la conclusión que el Fuenmayor testimoniaba un punto de inflexión en la poesía religiosa de justas en honor a santos entre Edad Media y Siglo de Oro:

${ }^{43} \mathrm{El}$ tema de la tormenta amorosa que se convierte en bonanza está presente ya en la lírica trovadórica con Raimbaut de Vaqueiras, Quan lo dous temps comensa: «Mout fai grant vilanatge / qui trop leus'espaventa, / q'apres lo fer auratge / vei qe.lh dous' aura venta». Véase Fabrizio Beggiato, «Percorso di un vettore tematico», in Dai siciliani ai siculo-toscani. Lingua, metro e stile per la definizione del canone. Atti del Convegno (Lecce, 21-23 aprile 1998), ed. de Rosario Coluccia y Riccardo Gualdo, Galatina, Congedo, 1999, pp. 155-166, p. 156, nota 2. 
La comparación de nuestro manuscrito de justas de fines del siglo Xvi con las de 1531-1541 recientemente reimpresas es extremamente interesante: no puede darse un cambio más evidente en medio siglo. Las justas de 1531-1541 apuntan tanto hacia el final de la Edad Media como las de 1584-1600 hacia el conceptismo del siglo XVII ${ }^{44}$.

En la historia cultural y literaria de la Antigüedad clásica al Barroco, pasando por la Edad Media y el Renacimiento, se asiste a una larga e ininterrumpida tradición de temas que impregnan y dan forma al discurso lírico sacro-profano. La influencia que la poesía religiosa ejerció en la difusión de este caudal lírico-iconográfico está aún poco estudiada. Desde el punto de vista aquí adoptado resultan evidentes las profundas resonancias de este patrimonio de imágenes líricas también en la poesía religiosa de poetas menores. Las nuevas aportaciones que se perfilan ayudarán a delinear con más exactitud los antecedentes literarios de alegorías muy recurrentes en los autos sacramentales de la literatura aurisecular.

Recibido: 16/06/2014

Aceptado: 7/09/2014

${ }^{44}$ Alonso, «Para la historia temprana», art. cit., p. 116. 


\section{(2)}

La NaVE de La iglesia de Bernardo de Toro y el BaJEL DE LA MaGdaLENa DE Luis DE AlCÁZAR: RECEPCIÓN A LO DIVINO DE MOTIVOS CLÁSICOS EN EL CANCIONERO SEVILLANO DE FUENMAYOR (SIGLOS XVI-XVII)

RESUMEN: La lírica a lo divino constituye un género que se desarrolla poderosamente a partir del siglo Xv, según una técnica de reescritura que culmina en la poesía de los grandes místicos del Renacimiento español. El Cancionero de Fuenmayor, códice sevillano de poesía religiosa de finales del siglo XVI, presenta un abundante caudal de vueltas a lo divino de temas, motivos, metáforas e imágenes poéticas propios de la poesía profana, como heridas, prisiones, fuentes y cazas de amor. En el presente estudio se analiza uno de los iconos más visitados por los autores del Fuenmayor, el motivo de la descriptio tempestatis, con las alegorías de la nave de la iglesia y del bajel o caravela de la Magdalena.

Palabras clave: Cancionero Fuenmayor. Bernardo de Toro. Luis Alcázar. Nave de la Iglesia. Bajel de la Magdalena. Reescritura a lo divino.

\section{The Nave de la iglesia By Bernardo de Toro and the Bajel de la Magdalena BY LUIS DE AlCÁZAR: A LO DIVINO RECEPTION OF CLASSICAL TOPICS In the Cancionero seVIllano de Fuenmayor $\left(16^{\mathrm{TH}}-17^{\mathrm{TH}}\right.$ CENTURies)}

ABSTRACT: The adaptation a lo divino of secular topics (themes, metaphors, motifs, images) is most popular during the $16^{\text {th }}$ and $17^{\text {th }}$ centuries, the Golden Age of Spanish literature. The Cancionero of Fuenmayor is a manuscript of religious poetry of the end of $16^{\text {th }}$ century, that includes an important number of contrafacta a lo divino. In this article I analize one of the most utilized topic from Fuenmayor's authors: the descriptio tempestatis, with allegory of the Ship of Church and of the vessel of the Magdalena.

Keywords: Cancionero Fuenmayor. Bernardo de Toro. Luis Alcázar. Ship of Church. Vessel of the Magdalena. Adaptation a lo divino. 